\title{
Chemistry of the Antarctic Boundary Layer and the Interface with Snow: an overview of the CHABLIS campaign
}

\author{
A. E. Jones ${ }^{1}$, E. W. Wolff ${ }^{1}$, R. A. Salmon ${ }^{1}$, S. J.-B. Bauguitte ${ }^{1}$, H. K. Roscoe $^{1}$, P. S. Anderson ${ }^{1}$, D. Ames ${ }^{2}$, \\ K. C. Clemitshaw ${ }^{2, *}$, Z. L. Fleming ${ }^{2, * *}$, W. J. Bloss ${ }^{3, * * *}$, D. E. Heard ${ }^{3}$, J. D. Lee ${ }^{3, * * * *}$, K. A. Read ${ }^{3, * * * *}$, P. Hamer $^{4}$, \\ D. E. Shallcross ${ }^{4}$, A. V. Jackson ${ }^{5}$, S. L. Walker ${ }^{5}$, A. C. Lewis ${ }^{6}$, G. P. Mills ${ }^{7}$, J. M. C. Plane ${ }^{7, * * * * *}$, A. Saiz-Lopez ${ }^{7, * * * * * * *}$, \\ W. T. Sturges ${ }^{7}$, and D. R. Worton ${ }^{7, * * * * * *}$ \\ ${ }^{1}$ British Antarctic Survey, Natural Environment Research Council, High Cross, Madingley Road, Cambridge, CB3 0ET, UK \\ ${ }^{2}$ Dept. of Environmental Science and Technology, Imperial College of Science, Technology and Medicine, Ascot, UK \\ ${ }^{3}$ School of Chemistry, University of Leeds, Woodhouse Lane, Leeds, LS2 9JT, UK \\ ${ }^{4}$ School of Chemistry, University of Bristol, Cantock's Close, Clifton, Bristol, BS8 1TS, UK \\ ${ }^{5}$ Institute for Atmospheric Science, School of Earth and Environment, University of Leeds, Leeds, LS2 9JT, UK \\ ${ }^{6}$ Department of Chemistry, University of York, Heslington, York, YO10 5DD, UK \\ ${ }^{7}$ University of East Anglia, School of Environmental Sciences, Norwich, NR4 7TJ, UK \\ *now at: Dept. Geology, Royal Holloway, University of London, Egham, Surrey, TW20 0EX, UK \\ ${ }^{* *}$ now at: University of Leicester, Leicester, UK \\ *** now at: School of Geography, Earth and Environmental Sci., Univ. of Birmingham, Edgbaston, Birmingham, B15 2TT, UK \\ **** now at: Department of Chemistry, University of York, Heslington, York, YO10 5DD, UK \\ ****** now at: School of Chemistry, University of Leeds, Woodhouse Lane, Leeds, LS2 9JT, UK \\ ******* now at: Earth And Space Science Division, Jet Propulsion Laboratory, California Institute of Technology, USA \\ ******** now at: Department of Environmental Science, Policy and Management, University of California - Berkeley, Berkeley, \\ CA 94720-3110, USA
}

Received: 20 December 2007 - Published in Atmos. Chem. Phys. Discuss.: 11 March 2008

Revised: 23 May 2008 - Accepted: 29 May 2008 - Published: 17 July 2008

\begin{abstract}
CHABLIS (Chemistry of the Antarctic Boundary Layer and the Interface with Snow) was a collaborative UK research project aimed at probing the detailed chemistry of the Antarctic boundary layer and the exchange of trace gases at the snow surface. The centre-piece to CHABLIS was the measurement campaign, conducted at the British Antarctic Survey station, Halley, in coastal Antarctica, from January 2004 through to February 2005. The campaign measurements covered an extremely wide range of species allowing investigations to be carried out within the broad context of boundary layer chemistry. Here we present an overview of the CHABLIS campaign. We provide details of the measurement location and introduce the Clean Air Sector Laboratory (CASLab) where the majority of the instruments were housed. We describe the meteorological conditions experienced during the campaign and present supporting chemical data, both of which provide a context within which to view the campaign results. Finally we provide a brief sum-
\end{abstract}

Correspondence to: A. E. Jones

(a.jones@bas.ac.uk) mary of highlights from the measurement campaign. Unexpectedly high halogen concentrations profoundly affect the chemistry of many species at Halley throughout the sunlit months, with a secondary role played by emissions from the snowpack. This overarching role for halogens in coastal Antarctic boundary layer chemistry was completely unanticipated, and the results have led to a step-change in our thinking and understanding.

\section{Introduction}

The Antarctic boundary layer is one of the regions of the world's atmosphere least affected by human activity. The continent is surrounded by the Southern Ocean with the nearest population centres being at much lower latitudes in the South American, African and Australian continents. The Antarctic boundary layer is a place of extremes; during the winter, the sun does not rise for months on end, contrasting with the summer which is light for 24 hours each day. Temperatures remain below zero for the majority of the year,

Published by Copernicus Publications on behalf of the European Geosciences Union. 
Table 1. List of CHABLIS participants, with the measurements made by each institution and details of the chemical instrumentation and techniques used.

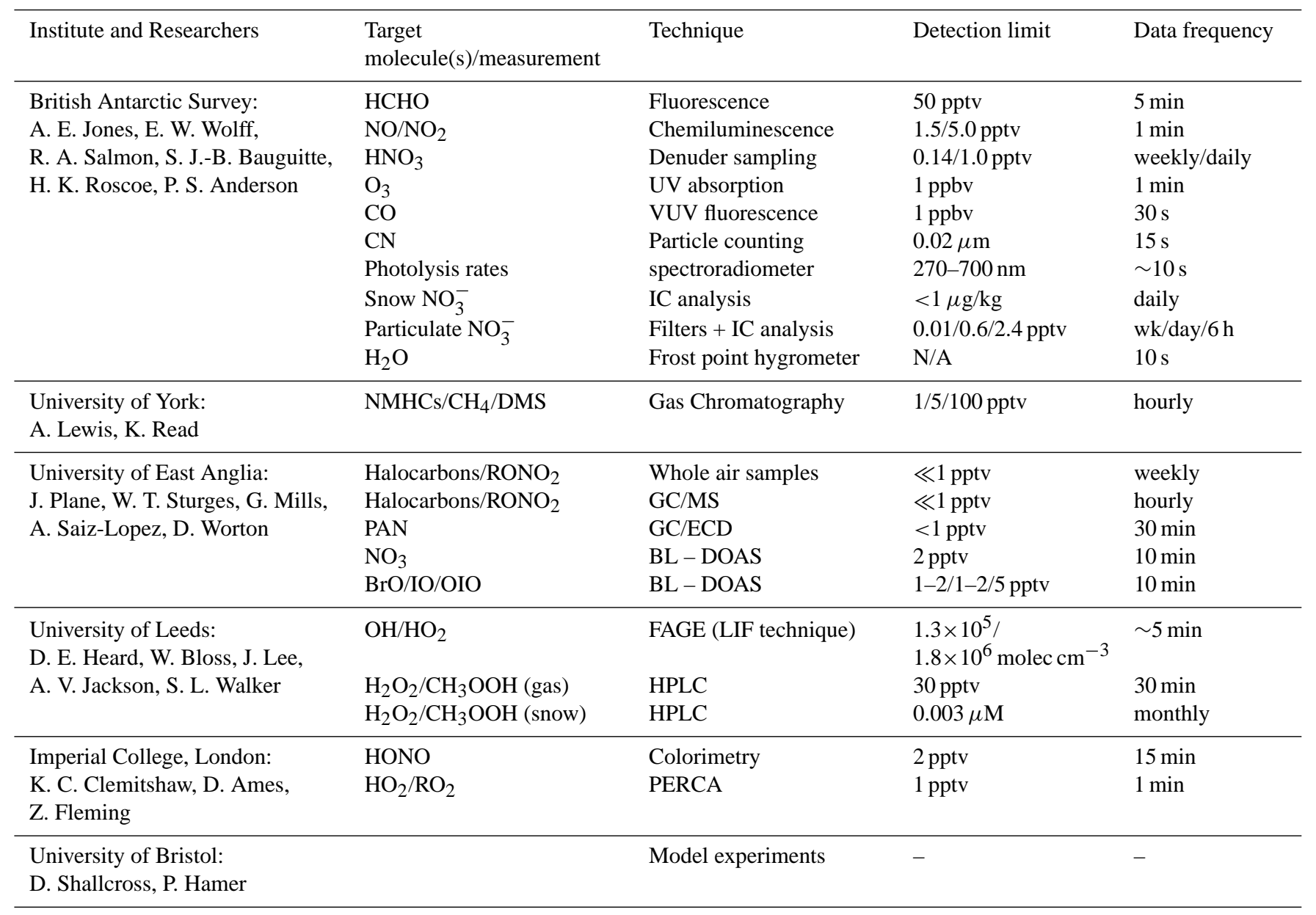

IC = Ion Chromatograph; GC-MS = Gas Chromatography - Mass Spectrometer; GC-ECD = Gas Chromatography - Electron Capture Detector; BL-DOAS = Boundary Layer- Differential Optical Absorption Spectrometer; FAGE = Fluorescence Assay by Gas Expansion; LIF = Laser Induced Fluorescence; HPLC = High Performance Liquid Chromatography, in this case with post-column derivatisation and fluorescence detection; PERCA = Peroxy Radical Chemical Amplifier

and even in coastal Antarctica can drop to $-50^{\circ} \mathrm{C}$. With this background, a study of Antarctic boundary layer chemistry can provide many things - a view of a natural atmosphere to be contrasted with more polluted regions; a challenging test bed for numerical models which simulate the atmosphere and climate of the future; and in addition, it provides a chance to deconstruct the chemistry, deposition and post-depositional processes which determine the record of impurities retrieved from deep ice cores.

The chemistry of the Antarctic troposphere has been relatively little studied to date. The earlier studies focused mainly on aerosols (e.g. Wolff et al., 1998) and long-lived radiatively and stratospherically important gases (e.g. Elkins et al., 1993; CMDL, 1996). Of the more reactive trace gases, only surface ozone was measured with any real vigour across the continent, with continuous sampling inland at South Pole (Oltmans and Komhyr, 1976) and on the coast, for example at Neumayer (Wyputta, 1994) and Syowa (Murayama et al., 1992). Data from the coastal stations are now recognised to also show springtime destruction of tropospheric ozone similar to that seen in the Arctic (Wessel et al., 1998). Recent years, however, have seen the first attempts to study the broader active background tropospheric chemistry and the interaction between air and snow. The SCATE (Sulfur Chemistry in the Antarctic Troposphere Experiment) campaign at Palmer Station on the Antarctic Peninsula (austral summer1993/94) (Berresheim and Eisele, 1998) focused on sulphur chemistry but included measurements for $\mathrm{O}_{3}, \mathrm{CO}$, $\mathrm{NO}, \mathrm{OH}$. Further year-round work on sulphur chemistry has been carried out at Dumont d'Urville station (Jourdain and 
Legrand, 2001). SCATE was followed up at South Pole by further summer programmes with a progressive shift towards focus on oxidants: ISCAT (Investigation of Sulfur Chemistry in the Antarctic Troposphere) in 1998 and 2000 (e.g. Davis et al., 2001; Davis et al., 2004). These studies have since been complemented by ANTCI (Antarctic Troposheric Chemistry Investigation) 2003 and 2005. Two campaigns were conducted at Neumayer, in austral summers 1997 and 1999 aimed at studying the budget and chemistry of $\mathrm{NO}_{\mathrm{y}}$ (e.g. Jones et al., 1999; Weller et al., 1999; Jacobi et al., 2000). In addition, measurements of tropospheric $\mathrm{H}_{2} \mathrm{O}_{2}$ and $\mathrm{HCHO}$ were run at Neumayer throughout 1997 (Riedel et al., 1999; Riedel et al., 2000), and of NO and $\mathrm{NO}_{\mathrm{y}}$ throughout 1999 (Weller et al., 2002), recognising the need for yearround measurement programmes. From the limited number of previous studies it was already clear that the Antarctic boundary layer behaved in very unexpected ways, driven by the extreme cold, long periods of darkness alternating with continuous sunlight, and a strong chemical coupling between the snowpack and the overlying atmosphere.

But in spite of these studies, the detailed chemistry of the Antarctic boundary layer remained little explored, in particular beyond the summer season. Progress was limited by the difficulty of assembling suitable facilities, instruments and researchers in the Antarctic, and in doing so for a time period long enough to unambiguously observe the underlying interactions at work. In response to this, CHABLIS (Chemistry of the Antarctic Boundary Layer and the Interface with Snow) was designed to explore the atmospheric chemistry of the Antarctic boundary layer in greater detail and for a longer period of time than had been previously achieved. It was a collaborative project between the British Antarctic Survey and research groups from five UK universities, and involved measurements made by an extensive range of chemical analysers as well as numerical modelling (see Table 1). The centre-piece to CHABLIS was a year-long field campaign to carry out measurements of Antarctic boundary layer chemistry and experiments to explore exchange processes between the snowpack and the overlying atmosphere.

\section{CHABLIS scientific aims}

The broad aims for CHABLIS outlined above, were distilled into three specific science foci: i) seasonal studies of oxidant chemistry which considered the potential role for $\mathrm{NO}_{3}$ during polar twilight/night, halogen chemistry during spring and summer, and HOx chemistry during polar summer; ii) year-round studies of the $\mathrm{NO}_{\mathrm{y}}$ budget aimed at determining the dominant $\mathrm{NO}_{\mathrm{y}}$ components, how they varied throughout the year, and what this meant both to sources of $\mathrm{NO}_{\mathrm{x}}$ and to ice core nitrate; iii) air/snow transfer studies, to assess the influence of the snowpack on coastal Antarctic boundary layer chemistry. Details of the measurement techniques are given in Table 1. The measurement strategy was for a co-ordinated

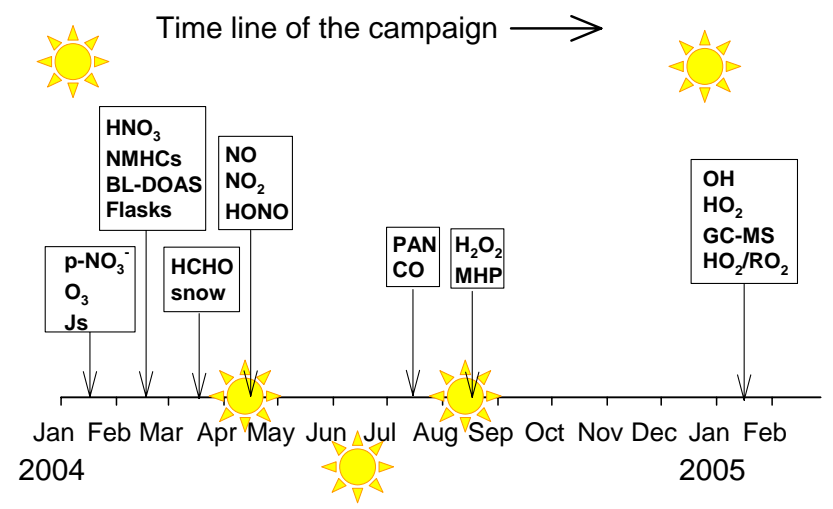

Fig. 1. Cartoon showing the point during the CHABLIS campaign at which instruments came on line. Periods of summer sunlight, as well as the onset and end of winter darkness, are denoted by the position of the sun above the nominal horizon suggested by the $\mathrm{x}$ axis.

study, beginning with a modest summer field campaign in 2003/04 extending into the 2004 Antarctic over-winter and spring period and culminating with a major summer intensive in the 2004/05 summer season. The overwinter campaign was run with two scientists on the ground who were responsible for set-up of most of the instruments. These consequently came on line progressively throughout the year, with the majority operational and capturing data from midwinter onwards. For the summer intensive, additional instruments were deployed, including FAGE (Fluorescence Assay by Gas Expansion) for $\mathrm{OH}$ and $\mathrm{HO}_{2}$, PERCA (Peroxy Radical Chemical Amplifier) for peroxy radicals, and a GC-MS for high resolution alkyl nitrates, alkyl halides and halocarbons. See Fig. 1 for details.

\section{Halley Research Station}

The field work was carried out at the British Antarctic Survey station, Halley $\left(75^{\circ} 35^{\prime} \mathrm{S}, 26^{\circ} 39^{\prime} \mathrm{W}\right)$, in coastal Antarctica (Fig. 2). Halley sits $32 \mathrm{~m}$ above sea level on the floating Brunt Ice shelf. The surrounding area is flat and snow-covered with the nearest rock outcrops roughly $200 \mathrm{~km}$ away. The station lies roughly $15 \mathrm{~km}$ inland, and as the coast effectively forms a promontory at this point, Halley is close to the Weddell Sea in three directions. During the summer months, an open water lead, that can be several tens of kilometers wide, extends along the ice front. Even during the winter, open water leads form regularly when easterly winds force the sea ice offshore. In particular, Precious Bay, to the south west of Halley, is normally ice free during winter and spring such that air arriving at Halley from this direction is likely to have had contact with open water. At Halley, the sun stays permanently above the horizon from 2 November to 9 February, and permanently below the horizon from 30 April 


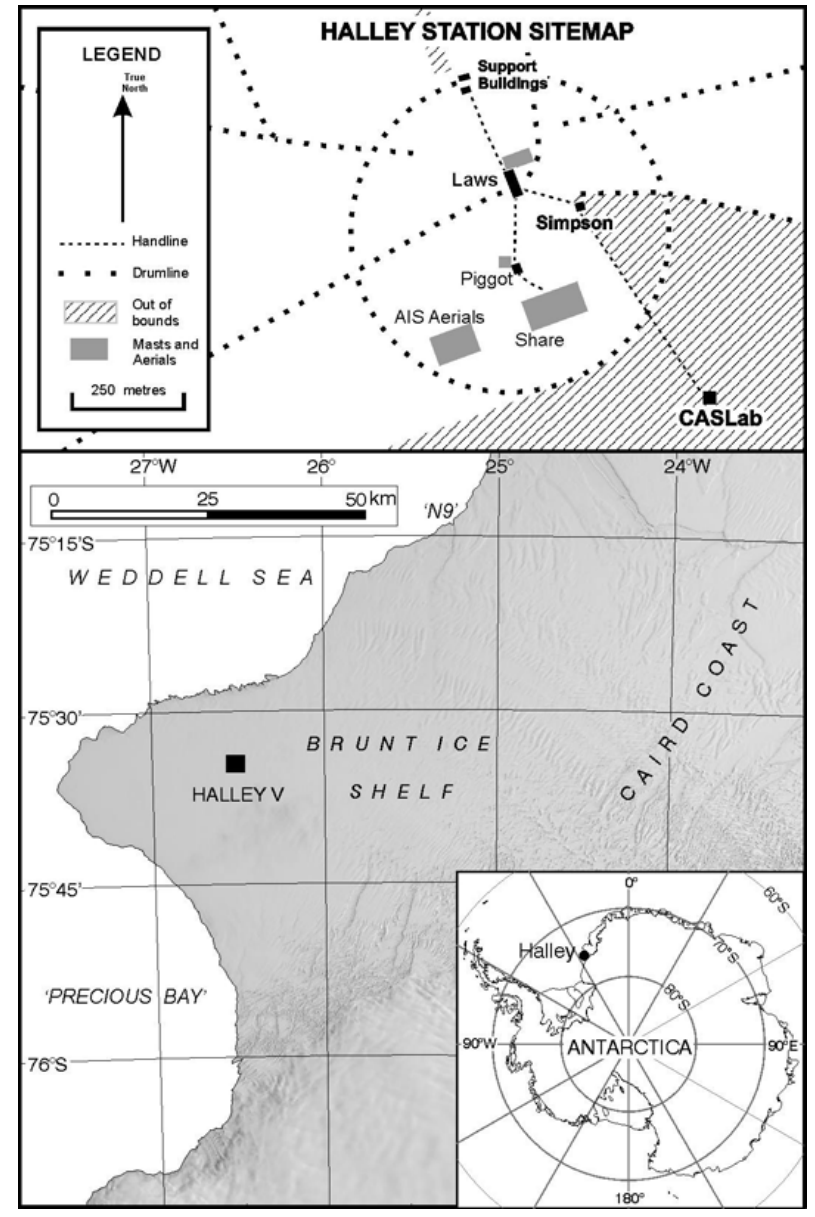

Fig. 2. Map of Halley, with details of the station lay-out and the location of the Clean Air Sector Laboratory (CASLab). The hashed area in the top panel is the clean air sector within which routine vehicular access is not allowed.

to 13 August. Prior to sun-up and after sun-down, scattered light can be observed at Halley for several hours around solar noon.

\section{The Clean Air Sector Laboratory}

The CHABLIS measurements were made at the new Clean Air Sector Laboratory (CASLab) (Fig. 3) which is designed specifically for studies of background atmospheric chemistry and air/snow exchange. The laboratory is constructed from three shipping containers, and mounted on a steel, legged platform that is raised approximately every two years in order to keep the platform roughly $3 \mathrm{~m}$ above the snow surface. The laboratory is situated $1 \mathrm{~km}$ to the south east of the main station, in a sector which receives minimal air flow from the base (see Fig. 2). Routine access is on ski or by foot, so interference from vehicle emissions is kept to an absolute minimum.

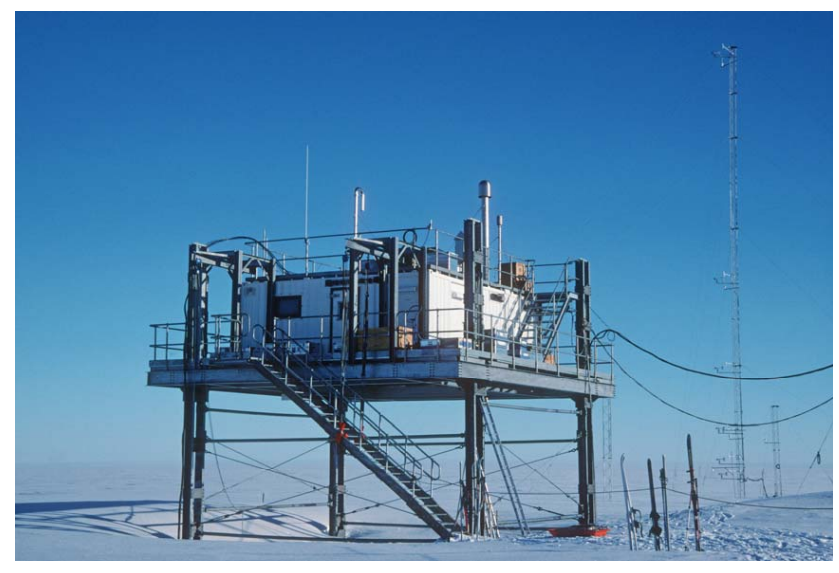

Fig. 3. The Clean Air Sector Laboratory (CASLab) at Halley. In the background is the $30 \mathrm{~m}$ mast for boundary layer meteorology experiments.

For all trace gas analysers housed in the CASLab (i.e. all but FAGE which was in its own container), ambient air was sampled off the main trace gas inlet stack. The stack comprises a $100 \mathrm{~mm}$ internal diameter (i.d.) electropolished stainless steel tube ventilated by a fan at the far end (see Fig. 4). The air flow through this central stack was $\sim 314 \mathrm{~m}^{3} / \mathrm{h}$, i.e. sufficiently high that the residence time within the stack was less than $1 \mathrm{~s}$. Additionally, the volume of air drawn through the stack was such that the samples removed less than $10 \%$ of the total air flow. Access to the air was achieved via individual ports, spaced $10 \mathrm{~cm}$ apart along the length of the stack, with $1 / 4^{\prime \prime}$ stainless steel tubing that penetrated to the centre of the air flow. Inlets to individual samplers were connected to these ports using Swagelock connectors. A Pitot tube monitored air flow through the stack during the CHABLIS campaign. The inlet of the central stack itself was initially $\sim 8 \mathrm{~m}$ above the snow surface. As the campaign progressed and snow accumulated during the year, this height reduced such that by the end of the campaign the inlet was $\sim 7 \mathrm{~m}$ above the snow surface.

Aerosol measurements were made from a separate stack specifically designed for particulate sampling. It comprises of a $200 \mathrm{~mm}$ i.d. stainless steel chimney with a cowl at the air intake to prevent snow ingress (see Fig. 5). Ventilation was achieved using a fan with a variable flow rate that can be altered according to the volume of air being drawn from the stack for sampling in order to allow isokinetic sampling. During CHABLIS, a stack flow rate of $2401 / \mathrm{min}$ was appropriate for the aerosol instrument suite: the low-volume filter sampler (flow rate $201 / \mathrm{min}$ ), the aethalometer (flow rate $201 / \mathrm{min}$ ) and the condensation particle counter (CPC, flow rate $11 / \mathrm{min}$ ). The samplers accessed the stack via stainless steel cones that were installed at the base of the chimney (see Fig. 5a and b). Each cone was specific to a particular instrument and was designed to maintain isokinetic flow up to the point of sampling. To achieve this, the ratio of the area of the 


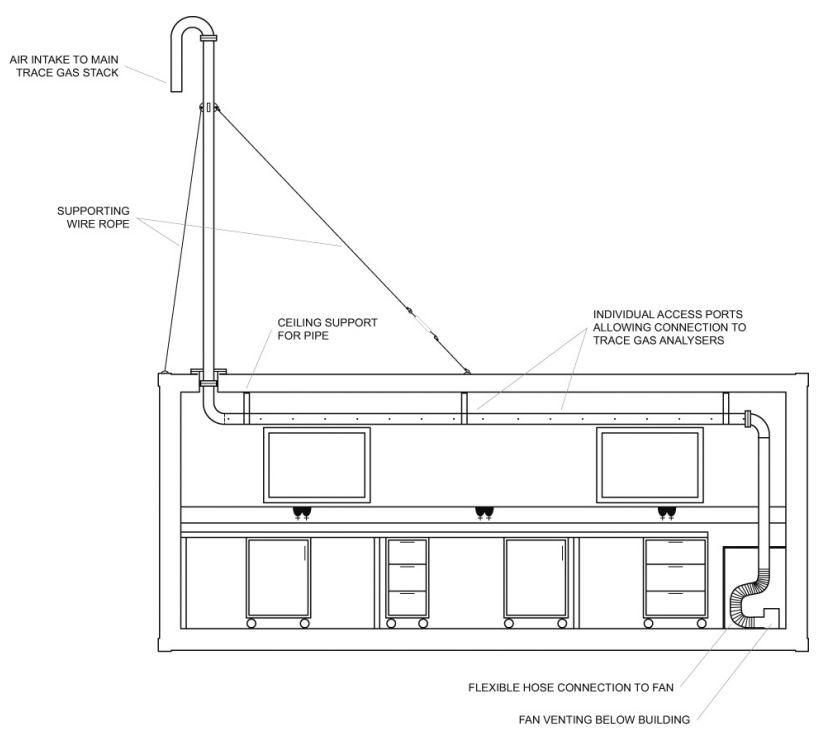

Fig. 4. A cross section through the CASLab showing the main trace gas sampling stack. Trace gas analysers accessed ambient air through individual access ports along the length of the stack. The CASLab is mounted on a platform roughly $3 \mathrm{~m}$ above the snow surface.

cone opening to the area of the stack tube needs to be equal to the ratio of the sampler flow rate to stack flow rate. For the low volume air sampler at $201 / \mathrm{min}$, this led to a diameter of the sampling cone of $57.6 \mathrm{~mm}$. The samplers then connected to the cones via swagelock connectors situated below the stack.

Particularly challenging for the CHABLIS set-up phase was the installation of the boundary layer differential optical absorption spectrometer (BL DOAS) system. This instrument records differential spectra between a light beam, emitted by a $400 \mathrm{~W}$ Xe arc lamp, and the return beam. In order to allow sufficient path length to achieve a satisfactory detection limit, the retro-reflector was located $4 \mathrm{~km}$ away from the CASLab. In order to keep the surfaces of the retro free from snow/ice, it was necessary to warm it. This was done by supplying $90 \mathrm{~W}$ of power from the CASLab to heaters at the retro-reflector along $4 \mathrm{~mm}^{2}$ cables over $5 \mathrm{~km}$ long.

In addition to the main CASLab facility, the Clean Air Sector includes a suite of external micro-meteorological instruments for probing the physics of the boundary layer. The suite of boundary layer measurements made during CHABLIS are summarised in Table 2. The instruments were mounted on a $30 \mathrm{~m}$ mast $50 \mathrm{~m}$ south of the laboratory, and located just beyond the air-flow distortion associated with the facility itself. In addition, the acoustic sounder and cospatial microbarograph array were situated $1 \mathrm{~km}$ north of the CASLab and operated for periods of the CHABLIS campaign. The combination of chemistry and physics instrumentation at the CASLab provided a powerful tool for interpreting the chemical measurements within the context of the physical behaviour of the boundary layer.

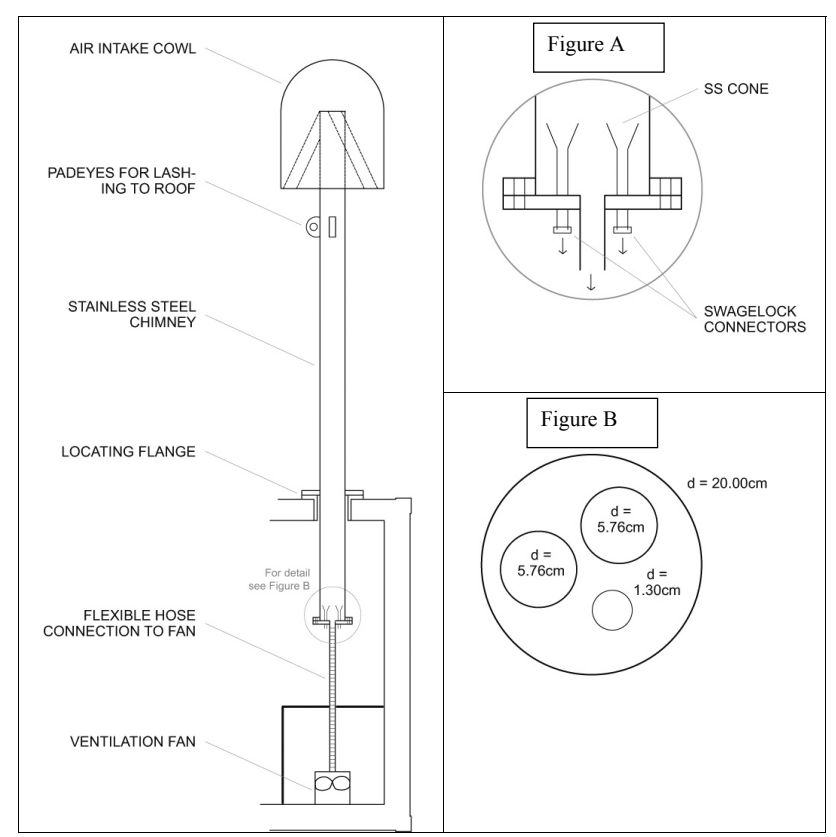

Fig. 5. Details of the air intake and sampling set up for the aerosol stack within the CASLab. Note that the drawings are not to scale.

\section{Meteorological conditions during CHABLIS}

The general meteorological conditions at Halley during the CHABLIS campaign are shown in Figs. 6 and 7, and are similar to those described from earlier years (König-Langlo et al., 1998). Figure 6 shows that surface temperatures ranged from around zero during the summer months to almost $-50^{\circ} \mathrm{C}$ during the late spring. Surface winds were generally between 0 and $10 \mathrm{~m} / \mathrm{s}$, with a number of storms throughout the year. The windiest period was during the spring, but a number of storms occurred also at other times of the year, including a particularly strong and sustained storm during May 2004. These storms tend to be associated with low pressure systems in the Southern Ocean that track the Antarctic coast and bring maritime air to Halley. Of interest also in this plot, and shown clearly for the May 2004 storm, is that periods of high winds are often associated with warmer temperatures; conversely, quiescent periods with low wind speeds tend to be colder.

The wind rose shown in Fig. 7 provides information not only on wind direction, but also on the strength of the winds (shown by the width of the bars). It demonstrates very clearly that the majority of winds during the campaign came from the east, and also that these were the strongest winds. It is also clear that for a significant proportion of the time during CHABLIS, winds came from the south west. Although local wind direction is not generally a good indicator of air mass origin, air arriving at Halley from the south west is likely to have had contact with open water in the Precious Bay region within the previous few hours. An important aspect is that 
Table 2. Summary of external boundary layer measurements made at Halley.

\begin{tabular}{|c|c|c|}
\hline Measurement & Resolution & Notes \\
\hline Snow temperature profile & $\begin{array}{l}10 \mathrm{~cm} \text { vertical } \\
0.05 \mathrm{~K} \\
10 \mathrm{~min}\end{array}$ & $\begin{array}{l}18 \text { white sheathed PRTs, gradually burying with } \\
\text { accumulation: initially } 7 \text { subsurface. }\end{array}$ \\
\hline Radiation & $\begin{array}{l}5 \mathrm{Wm}^{-2} \\
10 \mathrm{~min}^{-2}\end{array}$ & $\begin{array}{l}\text { global, reflected and diffuse shortwave. } \\
\text { Incoming and outgoing longwave }\end{array}$ \\
\hline Air Temperature & $\begin{array}{l}0.1 \mathrm{~K} \\
10 \mathrm{~min}\end{array}$ & $\begin{array}{l}1,2,4,8,16 \text { and } 32 \mathrm{~m} \text { nominal levels. } \\
\text { Aspirated PRT. }\end{array}$ \\
\hline RH & $2 \%$ & $1,2,4,8,16$ and $32 \mathrm{~m}$ nominal levels. HMP35D \\
\hline wind speed and direction & $0.3 \mathrm{~ms}^{-1}, 2^{\circ}$ & $\begin{array}{l}1,2,4,8,16 \text { and } 32 \mathrm{~m} \text { nominal levels. } \\
\text { Propeller vane }\end{array}$ \\
\hline Turbulent $u, v, w$ and $T$ & $\begin{array}{l}0.01 \mathrm{~ms}^{-1}, 0.2 \mathrm{~K} \\
40 \mathrm{~Hz}\end{array}$ & $\begin{array}{l}\text { 4, } 16 \text { and } 32 \mathrm{~m} \text { nominal levels, with three separate } \\
4 \mathrm{~m} \text { instruments deployed at varying distance from } \\
\text { CASLab to provide error sensitivity. }\end{array}$ \\
\hline RH turbulence & $40 \mathrm{~Hz}$ & $4 \mathrm{~m}$ nominal level \\
\hline
\end{tabular}

PRT = platinum resistance thermometer; HMP35D = Humidity probe (Vaisala Corp.)

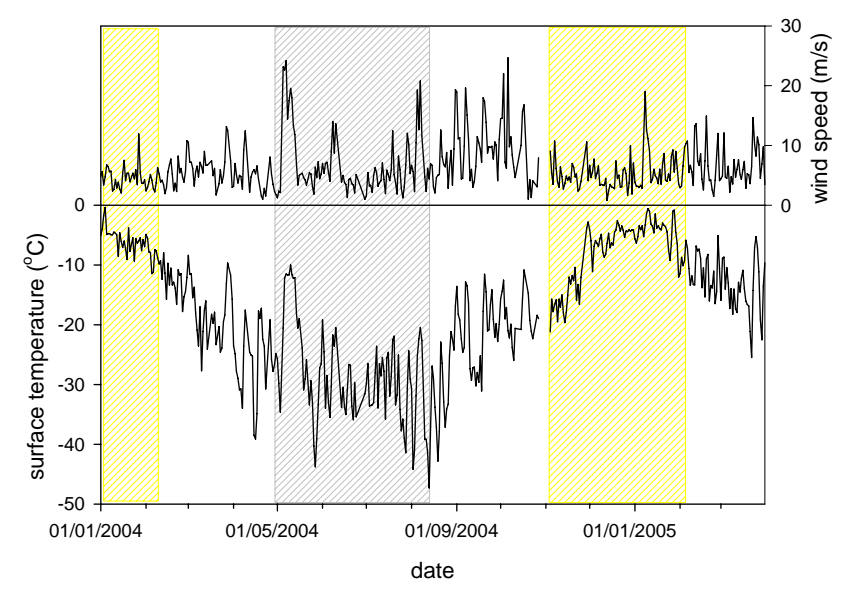

Fig. 6. Daily average wind speed (top panel) and surface temperatures (bottom panel) at Halley during the CHABLIS campaign (measurements made at $8 \mathrm{~m}$ above the snow surface). Periods when the sun did not set below the horizon are shaded yellow, and those when the sun did not rise above the horizon are shaded grey.

very few winds were from the northwesterly direction of the main station buildings.

The broader air mass origins can be derived from back trajectory calculations. 8-day back trajectories were calculated for the entire CHABLIS campaign using the web-based trajectory service of the British Atmospheric Data Centre (BADC) using input data from the European Centre for

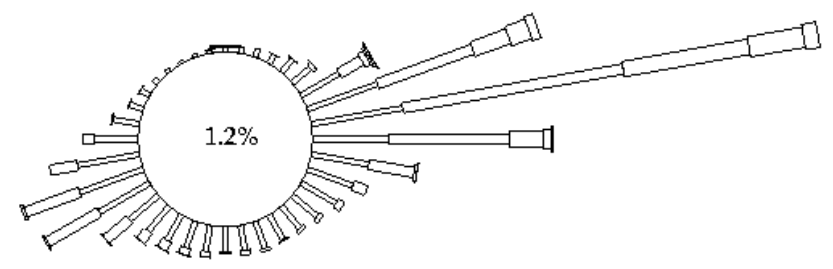

Fig. 7. Wind rose showing winds (measured at $8 \mathrm{~m}$ above the snow surface) experienced at Halley during the CHABLIS campaign (averaged from 1 April 2004 to 31 March 2005). The length of the bar indicates frequency of winds, and thickness indicates wind speed (i.e. $1.2 \%$ at $<0.5 \mathrm{~m} / \mathrm{s}$, then 0.5 to $5 \mathrm{~m} / \mathrm{s}, 5.5-10 \mathrm{~m} / \mathrm{s}, 10.5$ to $15 \mathrm{~m} / \mathrm{s}$, 15.5 to $20 \mathrm{~m} / \mathrm{s}, 20.5$ to $25 \mathrm{~m} / \mathrm{s}$ ).

Medium-Range Weather Forecasting (ECMWF). They show that during the campaign, air arrived at Halley from both the deep interior and the open ocean, so that a range of air mass types was probed.

Although the suite of boundary layer meteorology instrumentation at Halley includes an acoustic radar, this was unfortunately faulty during the period of the CHABLIS overwinter, coming on line again only in December 2004. However, data from previous years can be used to provide information on typical boundary layer conditions at Halley. For example, a study of the 2003 acoustic radar data (Dieudonne and Anderson, personal communication) showed that the height of the boundary layer during this year varied between 
$<40 \mathrm{~m}$ and $110 \mathrm{~m}$ above ground level, with a mean height of $70 \mathrm{~m}$. For the majority of the summer season (Dec/Jan/Feb) the boundary layer was near neutrally stratified, with occasions of convection around midday possible under suitable conditions associated with positive net radiation. During the winter (March through to November) the atmosphere was stable throughout, and only under conditions of moderate to strong winds was the boundary layer well mixed. Under very strong stability (light winds and clear skies) the upper atmosphere was effectively dislocated from the surface and very little vertical mixing could occur. Under stable conditions, any emissions of trace gases from the surface (e.g. the snowpack) would be concentrated in the lowest layers of the atmosphere, and considerable vertical gradients could be expected.

\section{Supporting chemical measurements}

Accompanying papers in this special issue explore the details of chemical composition and processes during the CHABLIS campaign. Here we present the chemical climatology as demonstrated by various measurements made during the campaign, and explore what some of these mean for boundary layer chemistry.

\subsection{Surface ozone}

Surface ozone was measured throughout the CHABLIS campaign using a 2B Technologies model 202 ozone monitor. This instrument was selected in part because of its extremely low power consumption $(\sim 4 \mathrm{~W})$ which is a great advantage when operating in remote regions. The analyser was connected directly to the trace gas inlet manifold and captured data every 10 seconds. The hourly-averaged time series is shown in Fig. 8. Surface ozone reaches its maximum concentration during the winter months and is at its minimum during the summer. This is the classic seasonal cycle for a trace gas whose concentration is balanced by increases arising from air mass transport and destruction by the direct action of the sun or by sunlight-initiated chemistry. Such a cycle is apparent at all other coastal Antarctic sites where surface ozone is measured (e.g. Neumayer, Syowa, McMurdo and Sanae (Helmig et al., 2007)). The cycle differs from that of South Pole, where surface ozone values decrease during spring from a winter peak before escalating rapidly towards a sharp annual maximum in summer (Crawford et al., 2001; Helmig et al., 2007). This unusual behaviour is associated with high mixing ratios of $\mathrm{NO}_{\mathrm{x}}$ which are themselves driven by emissions from the snowpack (Davis et al., 2001; Davis et al., 2004; Oncley et al., 2004); at sufficiently high $\mathrm{NO}_{2}$ mixing ratios, in situ ozone production occurs which dominates over loss processes (Crawford et al., 2001). Early results suggested that elevated $\mathrm{NO}_{\mathrm{x}}$ mixing ratios occurred under conditions of shallow boundary layer depths ( $20 \mathrm{~m}$ to $50 \mathrm{~m}$ )

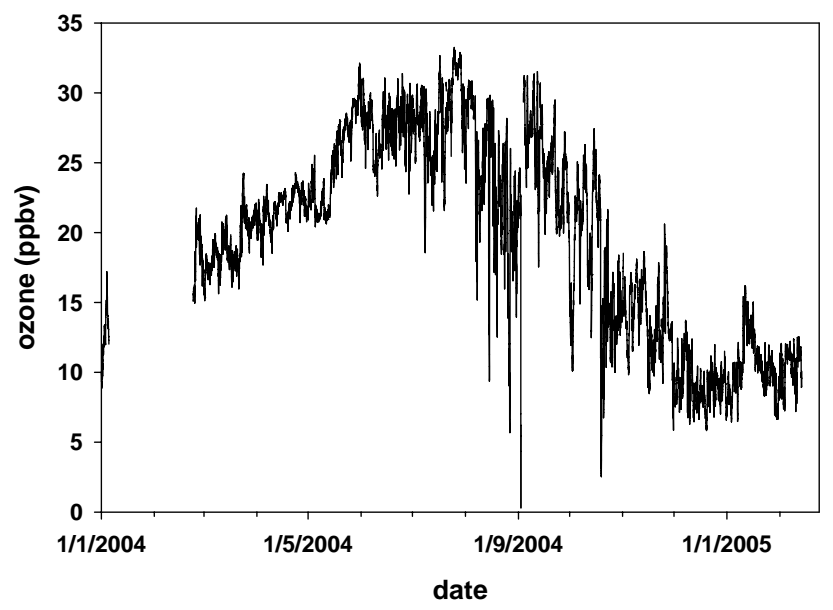

Fig. 8. Hourly average near-surface ozone measured throughout the CHABLIS campaign. Measurements were made from 1 January 2004 to 13 February 2005 apart from 6 January to 23 February 2004.

which were themselves associated with strong surface stability and light winds (Davis et al., 2004; Oncley et al., 2004). The picture was that trace gases produced from the snowpack were concentrated to a relatively high degree within this shallow layer. However, a recent study has found that the picture is somewhat more complicated, and that elevated NO mixing ratios can also occur under conditions of higher winds, weaker surface stability and deeper mixed layers (Neff et al., 2007). At Halley, the summertime boundary layer is normally deeper than that observed at South Pole; this factor will in part explain the lower surface $\mathrm{O}_{3}$ mixing ratios observed during summertime at Halley as $\mathrm{NO}_{\mathrm{x}}$ mixing ratios do not achieve the elevated levels observed at South Pole. However, an additional factor influencing surface ozone at Halley (and most likely all other coastal sites) is the presence of halogens. Measurements of $\mathrm{IO}$ and $\mathrm{BrO}$ made at Halley suggested that they were present throughout the summer at mixing ratios of the order 2 pptv, with typical peaks of 5 pptv (Saiz-Lopez et al., 2007). This inevitably suggests an associated presence of $\mathrm{I}$ and $\mathrm{Br}$ atoms which would be a significant sink for surface ozone (Bloss et al., 2007).

The influence of halogens on surface ozone is also clearly apparent during springtime. Figure 8 shows the springtime ozone depletion events (ODEs), previously seen at Halley (Jones et al., 2006) and indeed a commonly-recognised feature at coastal sites in both polar regions (e.g. Simpson et al., 2007). Interestingly, a deep and rapid ODE lasting for just under a day was measured on 19 October which is surprisingly late in the season.

\subsection{Carbon monoxide}

The instrument used for measuring carbon monoxide was the AeroLaser Fast CO Monitor, Model AL 5001, which employs the technique of vacuum ultra-violet (VUV) fluorescence for determination of CO. Data were captured in 


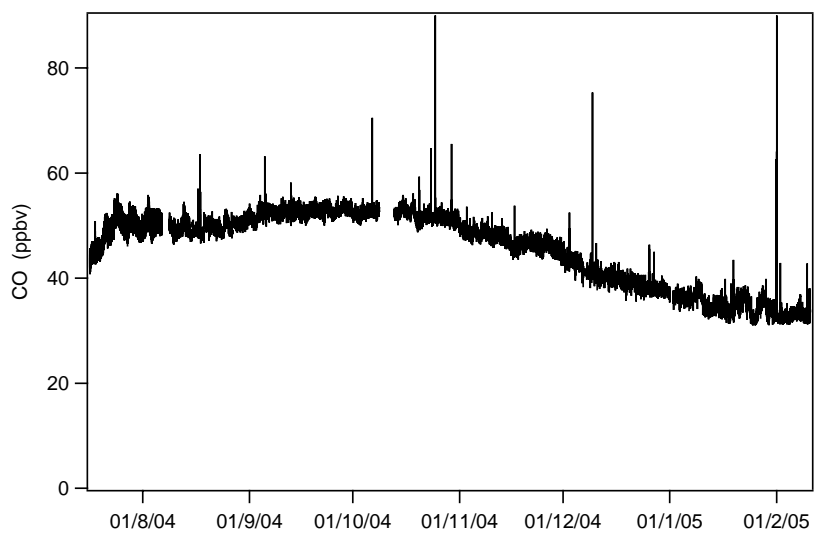

Fig. 9. Timeseries of $\mathrm{CO}$ measurements made during the CHABLIS campaign. Data were captured from July 2004 through to February 2005. The very short-lived spikes are associated with exhaust emissions from the main station, and were used to produce a pollution inventory against which other data could be filtered.

real time from July 2004 until February 2005. Two sampling protocols were adopted. Up until 6 August 2004, the measurement duty cycle included 5 min long, hourly calibration/zeroing sequences, the data were logged at $10 \mathrm{~s}$ intervals with no smoothing; this yielded a standard deviation for a one hour data sample (at low atmospheric variability) of $0.7 \mathrm{ppbv}$. After 6 August 2004, the duty cycle comprised $10 \mathrm{~min}$ long, 12 hourly calibration/zeroing sequences, the data were logged at $30 \mathrm{~s}$ intervals, with a $60 \mathrm{~s}$ running average; this yielded a standard deviation for a one hour data sample (at low atmospheric variability) of $0.2 \mathrm{ppbv}$. The timeseries measured during the CHABLIS campaign is shown in Fig. 9, with the anticipated mid-winter maximum and summer minimum. The very short-lived spikes are associated with exhaust emissions from the main station, and were used to produce a pollution inventory against which other data could be filtered. These data and issues of CO calibration and standardisation are discussed by Bauguitte et al. $(2008)^{1}$.

\subsection{Inorganic nitrate}

\subsubsection{Nitric acid}

Nitric acid is notoriously difficult to collect and measure because of its tendency to stick to any available surface (see e.g. Ryerson et al., 1999). Apart from the more expensive routes (such as Chemical Ionisation Mass Spectrometry), three main methods have been used to sample $\mathrm{HNO}_{3}$ in the past: nylon filters, annular denuders, and mist chambers.

\footnotetext{
${ }^{1}$ Bauguitte, S. J.-B., Jones, A. E., Brough, N., and Wolff, E. W.: Carbon monoxide measurements in coastal Antarctica and issues regarding standardisation, Atmos. Chem. Phys. Discuss. in preparation, 2008.
}

For CHABLIS, annular denuders (URG corporation) were used to sample $\mathrm{HNO}_{3}$. For the routine measurements two denuders were used in series, each denuder being $150 \mathrm{~mm}$ long, $30 \mathrm{~mm}$ outside diameter and with 3 concentric channels. The second denuder acted as a back-up from which collection efficiency could be derived.

Before use, each denuder was coated with a solution made up from $1 \mathrm{~g} \mathrm{Na}_{2} \mathrm{CO}_{3}$ (sodium carbonate), $1 \mathrm{~g}$ glycerol in $50 \mathrm{~mL}$ Milli-Q water plus $50 \mathrm{~mL}$ methanol; the denuders were then dried in a clean air stream and capped at either end. For sampling, the denuder train was installed on the roof of the CASLab to allow open-face sampling and ensure minimal losses of $\mathrm{HNO}_{3}$ to surfaces. Air was pumped through the denuder train at a flow rate of $201 / \mathrm{min}$. Denuders were exposed for periods of 1 week throughout the campaign, and in each season for a week, daily sampling was conducted as well as one day at 6-hourly resolution. After sampling, the denuder coating was rinsed off using a known amount of MilliQ water $(18 \mathrm{M} \Omega)$ and the liquid was frozen and returned to the UK for analysis. This was carried out using an ion chromatograph (IC).

The collection efficiency was assessed throughout the campaign by comparing $\mathrm{HNO}_{3}$ sampled on the first denuder with that sampled on the second (both initially blankcorrected):

collection efficiency $=1-($ denuder $2 /$ denuder 1$)$

During CHABLIS, $\mathrm{HNO}_{3}$ was sampled with a collection efficiency of $91 \%$. Blanks were assessed every 3 months by connecting an additional denuder to the sampling train. The third denuder acted as the blank, the assumption being that no significant amount of ambient $\mathrm{HNO}_{3}$ would break through into this denuder.

When working up the data, the amount of $\mathrm{HNO}_{3}$ in the boundary layer was calculated according to:

total sample $=($ denuder $1-$ blank $) /$ collection efficiency

The detection limit for $\mathrm{HNO}_{3}$ sampling (derived from $2 \times$ standard deviation of the blank) varied from $0.14 \mathrm{pptv}$ for weekly sampling to $1 \mathrm{pptv}$ for daily sampling. For the 6-hourly sampling, unfortunately all the data were below the detection limit of 4 pptv. The $\mathrm{HNO}_{3}$ measurements made during CHABLIS are shown at their highest resolution in Fig. 10a and are further discussed in Jones et al. (2007).

\subsubsection{Particulate nitrate}

Particulate nitrate was sampled through the main aerosol inlet within the CASLab, on $1 \mu \mathrm{m}$ pore size, $37 \mathrm{~mm}$ diameter Zefluor filters (Pall-Gelman Corp.), at a flow rate of $\sim 201 / \mathrm{min}$. Again, filters were exposed for periods of 1 week throughout the majority of the campaign, but with higher resolution (daily and 6-hourly) in each season. Handling 


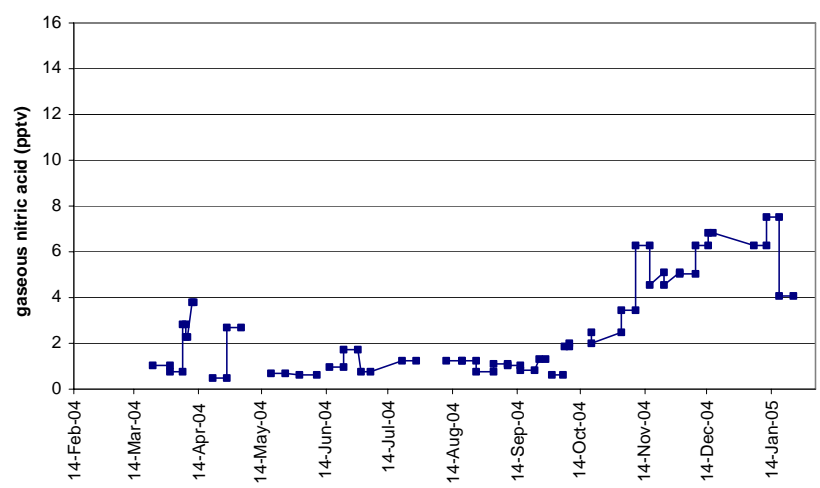

Fig. 10a. Year-round $\mathrm{HNO}_{3}$ from denuders at weekly and daily sampling frequency, plotted on same y-axis scale as Fig. 10b to ease comparison. Only limited numbers of daily samples were above the detection limit, (6, 7, 10 April; 6, 8 October).

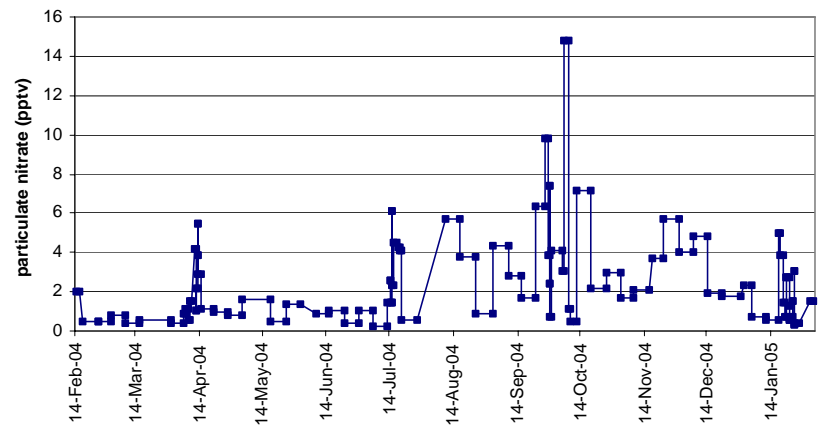

Fig. 10b. Year-round particulate nitrate from filter sampling at weekly, daily and 6-hourly sampling resolution. Higher resolution sampling was carried out around mid April, mid July, end September/early October, and mid January.

blanks were run approximately every 3 months, during which the filter was installed as normal but the pump switched on only for a few seconds before changing the filter. Once exposed, all filters were stored frozen and returned to the UK for analysis. Filters were extracted into $\sim 8 \mathrm{ml}$ of MilliQ water $(18 \mathrm{M} \Omega)$ by agitating in an ultrasound bath. The extract was then analysed for major cations (e.g. $\mathrm{Na}^{+}, \mathrm{Ca}^{+}$) and anions (e.g. $\mathrm{NO}_{3}^{-}$, methane sulphonic acid) using an IC. Lowvolume aerosol filters operated in this way are assumed to sample aerosol with $100 \%$ efficiency. Throughout this paper particulate nitrate measurements are expressed in pptv, where $1 \mathrm{pptv}$ is equivalent to $2.78 \mathrm{ng} \mathrm{m}^{-3}$. Detection limits were derived from $2 \times$ standard deviation of the blanks, and varied from $0.01 \mathrm{pptv}$ for weekly sampling to $2.4 \mathrm{pptv}$ for 6-hourly sampling (see Table 1). The low-volume aerosol $p-\mathrm{NO}_{3}^{-}$data, blank corrected, are shown at their highest resolution in Fig. 10b. These and other low-vol data are more fully analysed in other papers in this special issue (Jones et al., 2007; Wolff et al., 2008).

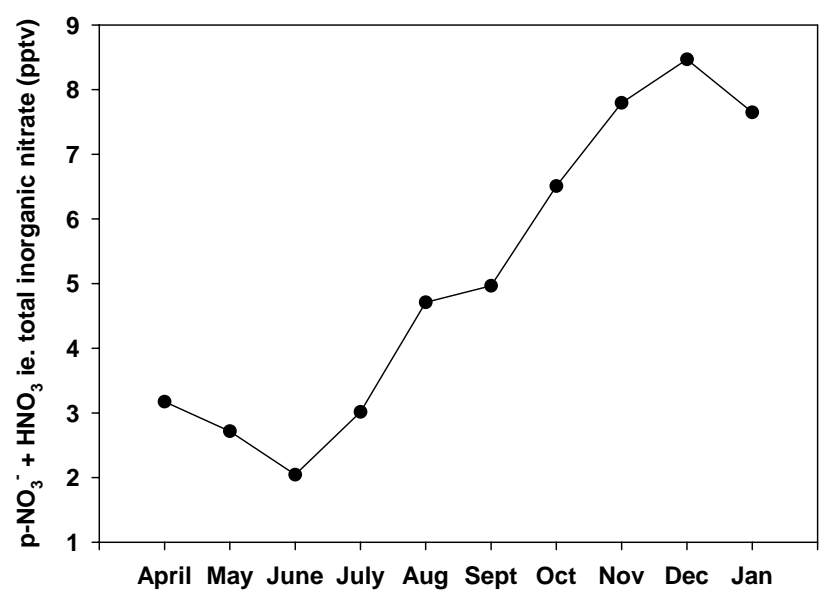

Fig. 11. The sum of nitric acid and particulate nitrate, often referred to as total inorganic nitrate, as measured on denuders and low-volume filters during CHABLIS.

\subsubsection{Total inorganic nitrate}

Here we briefly consider the monthly averaged "total inorganic nitrate" (TIN $=\mathrm{HNO}_{3}+p$ - $\mathrm{NO}_{3}^{-}$) data for CHABLIS, which is shown in Fig. 11. The peak in summer (NovDec-Jan) and shoulder suggesting a possible secondary peak in August are consistent with observations at both Neumayer (Wagenbach et al., 1998) and Dumont d'Urville, a coastal station in the Pacific sector of Antarctica. High volume aerosol filters (assumed to capture both particulate and gaseous nitrate) from Dumont d'Urville were analysed both for their nitrate concentration and isotopic signature (Savarino et al., 2007). The authors concluded that the two nitrate peaks were driven by quite separate mechanisms. The summertime peak was interpreted as arising from snowpack emissions on the polar plateau which were recycled and transported to the coastal region. Polar stratospheric cloud (PSC) sedimentation was concluded to be responsible for the late winter/early spring TIN peak. Certainly measurements of tritium, a marker of stratospheric water and hence PSCs, reported for Halley from 1983 to 1992 (Wagenbach et al., 1998) reveal a maximum in August/September.

\subsection{Snow sampling}

\subsubsection{Surface snow}

Surface snow was collected on a daily basis during CHABLIS from March 2004 until the end of the measurement campaign. An area of clean snow was selected, roughly $50 \mathrm{~m}$ to the south west of the CASLab. This area was remote from the station, undisturbed by vehicle traffic of any sort, and therefore provided pristine snow for sampling.

Using clean procedures (i.e. wearing clean-room gloves and not breathing into the sample), snow was collected 

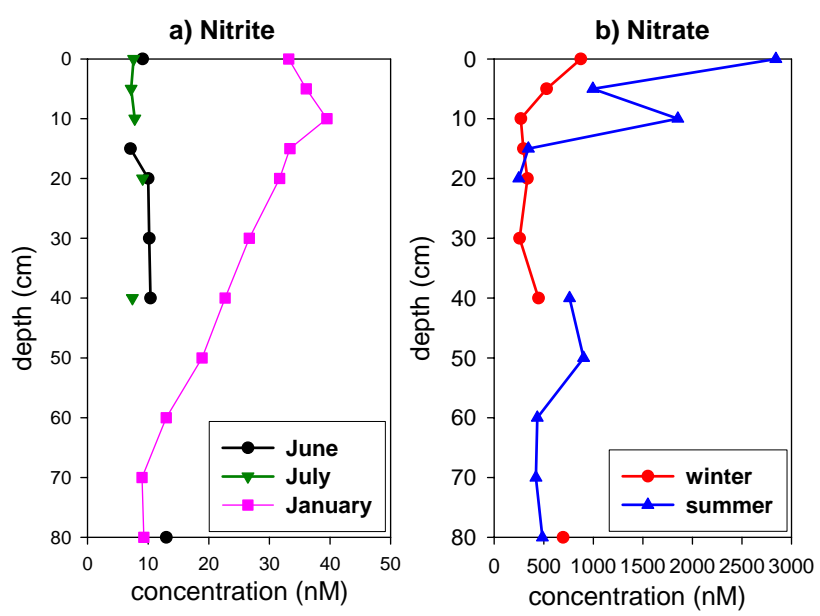

Fig. 12. Snow pit profiles of (a) nitrite $\left(\mathrm{NO}_{2}^{-}\right)$and (b) nitrate $\left(\mathrm{NO}_{3}^{-}\right)$during winter and summer months. The nitrite profiles show individual months whereas those for nitrate are averages of June and July (for winter) and December and January (for summer).

directly into clean accuvettes to a depth of roughly $1 \mathrm{~cm}$. The samples were stored frozen and returned to the UK at the end of the measurement campaign where they were analysed on an IC for major anions and cations $\mathrm{Na}^{+}, \mathrm{K}^{+}, \mathrm{Ca}^{2+}, \mathrm{Mg}^{2+}$, $\mathrm{F}^{-}$, MSA, $\mathrm{Cl}^{-}, \mathrm{NO}_{3}^{-}, \mathrm{SO}_{4}^{2-}$ ). Surface snow data are discussed in various papers in this special issue, e.g. Jones et al. (2007) and Wolff et al. (2008).

\subsubsection{Snow pit measurements (nitrate and nitrite)}

Snow pits were dug each month during the CHABLIS campaign, in a similar location to the surface snow sampling and again using clean procedures to limit contamination. The pits were sampled at a series of depths between the surface and $80 \mathrm{~cm}$, by pushing cleaned Perspex bottles directly into the wall of the pit. As the diameter of the bottles is $3 \mathrm{~cm}$, the resolution of each snow pit sample was the desired depth $\pm 1.5 \mathrm{~cm}$. Snow samples for nitrate analysis were stored frozen and returned to the UK for analysis on the BAS IC. This approach relies on the fact that nitrate is stable within snow when stored frozen and in the dark. Snow samples for nitrite, however, were analysed at Halley using the HONO analyser which, given it uses a liquid method for sample analysis, was ideal for determining nitrite in melted snow. The samples were stored frozen and in the dark and were analysed within a few days.

Figure 12a shows the depth profile of nitrite in the top $80 \mathrm{~cm}$ of the Halley snow pack for June, July (winter) and January (summer). The June and July profiles effectively overlap, displaying essentially no variation within this depth range. January, however, is markedly different, with a very clear maximum in the top 0 to $15 \mathrm{cms}$, which gradually decreases with depth until it coincides with the wintertime pro- files at around $60 \mathrm{~cm}$. This behaviour is characteristic of a snow impurity that has a maximum during the summer months. At Halley, with roughly a meter of snowfall each year, sampling to only $80 \mathrm{~cm}$ depth would not reach the previous summer's maximum assuming that it was preserved. The trend in the nitrite profile is very similar to that for nitrate, shown in Fig. 12b; concentrations of nitrate in surface snow have a maximum during the summer and minima in the winter (Jones et al., 2007).

Of particular interest in Fig. 12 are the comparative concentrations of nitrate and nitrite, with summertime nitrate exceeding that of nitrite by 2 orders of magnitude. Abundant data exist for concentrations of nitrate in polar snow and ice, however, there are extremely few reported measurements of nitrite. A likely reason for this are the very low concentrations of nitrite, that would take it below the detection limit of many analysis systems. One previous set of measurements was made during the spring in Barrow, Alaska ( $\mathrm{Li}$, 1993) where surface snow nitrate concentrations were typically around the instrument detection limit of $40 \mathrm{nM}$. Two recent papers have calculated nitrite concentrations in snow. Jacobi and Hilker (2007) used a model derived from laboratory experiments and applied it to field data to calculate nitrite concentrations in summertime snow at Summit, Greenland, of less than $0.0002 \mathrm{nM}$. Chu and Anastasio (2007) calculated concentrations of snow grain nitrite based on steady state analysis of sources and sinks for four polar locations. Their estimates ranged from $0.7 \mathrm{nM}$ (for Alert) to $13 \mathrm{nM}$ (for Summit). For Neumayer $\left(70^{\circ} \mathrm{S}, 8^{\circ} \mathrm{W}\right)$, a coastal site in the same sector of Antarctica as Halley, nitrite concentrations of $5 \mathrm{nM}$ were calculated for noon solstice (21 December) conditions.

The interest in comparing nitrite and nitrate snow pack concentrations stems from the fact that both are potential sources of $\mathrm{OH}$ (although their direct contribution has been shown to be considerably less than that from $\mathrm{H}_{2} \mathrm{O}_{2}$ for example (Chu and Anastasio, 2007), and also sources of $\mathrm{NO}_{\mathrm{x}}$. Nitrate is photolysed to directly produce $\mathrm{NO}_{2}$ via its major channel:

$\mathrm{NO}_{3}^{-}+h v \rightarrow \mathrm{NO}_{2}+\mathrm{O}^{-}$

and nitrite photolysis generates NO:

$\mathrm{NO}_{2}^{-}+h v \rightarrow \mathrm{NO}+\mathrm{O}^{-}$

Nitrite itself can be formed from the minor photolysis channel of nitrate $\left(\mathrm{NO}_{3}^{-}+h \nu \rightarrow \mathrm{NO}_{2}^{-}+\mathrm{O}\left({ }^{3} \mathrm{P}\right)\right)$ as well as from hydrolysis of $\mathrm{NO}_{2}$ generated by Reaction 1 .

The fact that nitrite is photolysed at somewhat longer wavelengths than nitrate $(320-400 \mathrm{~nm}$ as opposed to 280 $320 \mathrm{~nm}$ ) results in significantly higher photolysis rates for nitrite than for nitrate under natural sunlit conditions. Chu and Anastasio (2007) calculated photolysis rates for R1 and R2 appropriate for Neumayer (for noon 21 December) and found that those for nitrite were two orders of magnitude 
higher than for nitrate. We use their calculated photolysis rates and our measurements of nitrite and nitrate in the top of the summertime snow pits to derive relative production rates for $\mathrm{NO}_{\mathrm{x}}$ (see Table 3). The ratio of $\mathrm{NO}_{\mathrm{x}}$ produced by photolysis of nitrite to that from nitrate under these conditions is 1: 0.69 , i.e. an equivalent order of magnitude from both sources. This approach considers only surface snow and does not take into account photolysis occurring deeper within the snow pack. However, the production with depth is expected to scale linearly for both species, so this additional factor is not likely to significantly alter the ratio. However, it must be remembered that surface snow nitrate concentrations display considerable heterogeneity; for example, at Halley the average surface snow nitrate concentration for the months of 4 December and 5 January is $2630 \pm 982 \mathrm{nM}$, with a range from $801 \mathrm{nM}$ to $6015 \mathrm{nM}$. Unfortunately, we have no additional nitrite data to explore whether equivalent heterogeneity exists for this species such that the $\mathrm{NO}_{\mathrm{x}}$ production ratio is preserved, or whether the ratio varies. However, the results do illustrate that, at least at Halley, nitrite, albeit at low concentrations in the snow, can be a very significant source of $\mathrm{NO}_{\mathrm{x}}$. This conclusion, arrived at from measurements, agrees with that of Chu and Anastasio (2007) who made this suggestion based on calculations. What it means is that numerical models that aim to calculate fluxes of $\mathrm{NO}_{\mathrm{x}}$ from snow (and indeed those probing the chemistry of snow-pack and its interstitial air) should include a comprehensive suite of reactions to account for nitrite formation and subsequent photolysis.

6.5 Measurements of the ratio of up-welling to downwelling actinic flux

During CHABLIS, a spectroradiometer was used to derive photolysis frequencies for a number of trace gases, and to measure the ratio of up-welling to down-welling actinic flux. The purpose of the flux-ratio measurements was to provide parameterisations suitable for use by modellers. For this purpose, an accuracy of a few percent is quite adequate, unlike in climate and snow-character studies where an accuracy of better than $1 \%$ would be important (for some modelling studies, even an estimate of up-welling flux within $10 \%$ might be considered sufficient).

The albedo A is defined by the ratio of upward to downward irradiance, i.e. measurements by horizontal cosineresponse (flat plate) sensors. The ratio of up-welling to down-welling actinic flux measurements, by isotropicresponse (hemispheric) sensors, only equals $\mathrm{A}$ in the idealised case of an isotropic diffuse sky with no reflectivity (Madronich 1987). The ratio is $2 A \cos (\mathrm{SZA})$ under clear skies if Rayleigh scattering by air molecules is ignored. If the surface is snow, the ratio is close to 1.0 in the more realistic diffuse sky case of thick cloud, even if $A$ is less than 0.9, because multiple reflections between snow and cloud ensure near-equal up-welling and down-welling fluxes.
Table 3. Comparing photolysis rates, surface snow concentrations (measured at the surface of the snowpits), and the consequent ratio in $\mathrm{NO}_{\mathrm{x}}$ production rate from nitrite and nitrate in snow. The photolysis rates are for $j\left(\mathrm{NO}_{2}^{-} \rightarrow \mathrm{NO}\right)$ and $j\left(\mathrm{NO}_{3}^{-} \rightarrow \mathrm{NO}_{2}\right)$ respectively for noon 21 December conditions (Chu and Anastasio, 2007).

\begin{tabular}{lcc}
\hline & nitrite & nitrate \\
\hline photolysis rate $\left(\mathrm{s}^{-1}\right)$ & $3.5 \times 10^{-5}$ & $2.8 \times 10^{-7}$ \\
snow concentration $(\mathrm{nM})$ & 33.2 & 2843 \\
ratio & 1 & 0.69 \\
\hline
\end{tabular}

Some models calculate actinic flux from first principles, and so include a comprehensive treatment of up-welling actinic flux, including the calculation of Rayleigh scattering and $2 A \cos (\mathrm{SZA})$ together with multiple reflections between cloud and snow. These models need the albedo $\mathrm{A}$ as an input. Irradiance measurements by cosine-response sensors have been carried out routinely at Halley for many years, and were evaluated from 1963 to 1982 by Gardiner and Shanklin (1989) in their Table 9b. Monthly-mean albedos varied from 0.81 to $0.83,0.03$ to 0.05 , with no clear seasonal cycle. We therefore recommend a value of albedo of 0.820 .06 .

However, some users of CHABLIS data need as input an estimate of total actinic flux from measurements. This can be derived from the near-continuous CHABLIS measurements of down-welling flux by multiplying by $(1+$ upwelling/down-welling flux), hence they need an empirical evaluation of up-welling/down-welling flux. Below we show measurements of the flux ratio and derive a simple parameterisation.

The actinic flux instrument used was a single monochromator with a diode array detector (meteorologieconsult gmbh, (Hofzumahaus et al., 2004)). It uses a 512 pixels diode array detector, mounted in a fixed-grating monolithic monochromator (Zeiss), covering the spectral range from 270 to $700 \mathrm{~nm}$. The input optics were heated to prevent riming. Spectra were digitised to 16 bits (MOE C161, TEC 5 AG, Germany), and the values transmitted to the CASLab computer, $150 \mathrm{~m}$ away, via RS422 serial communication. The instrument was calibrated at 6 month intervals using a spectral irradiance standard consisting of a 1000 Watt quartz halogen tungsten filament lamp model FEL A (Optronics Laboratories).

Normally, the actinic flux spectrometer measured the down-welling hemispheric flux by observing vertically upward via a quartz hemisphere ground on the inside (conventionally known as a $2 \pi$ dome). A black horizontal plate and ring defined the lowest angle seen. From time to time during the summer, measurements of the up-welling flux were made by pointing the spectrometer vertically downward towards the snow $2.5 \mathrm{~m}$ below. The process of unclamping the spectrometer from its mounting frame, rotating it and 

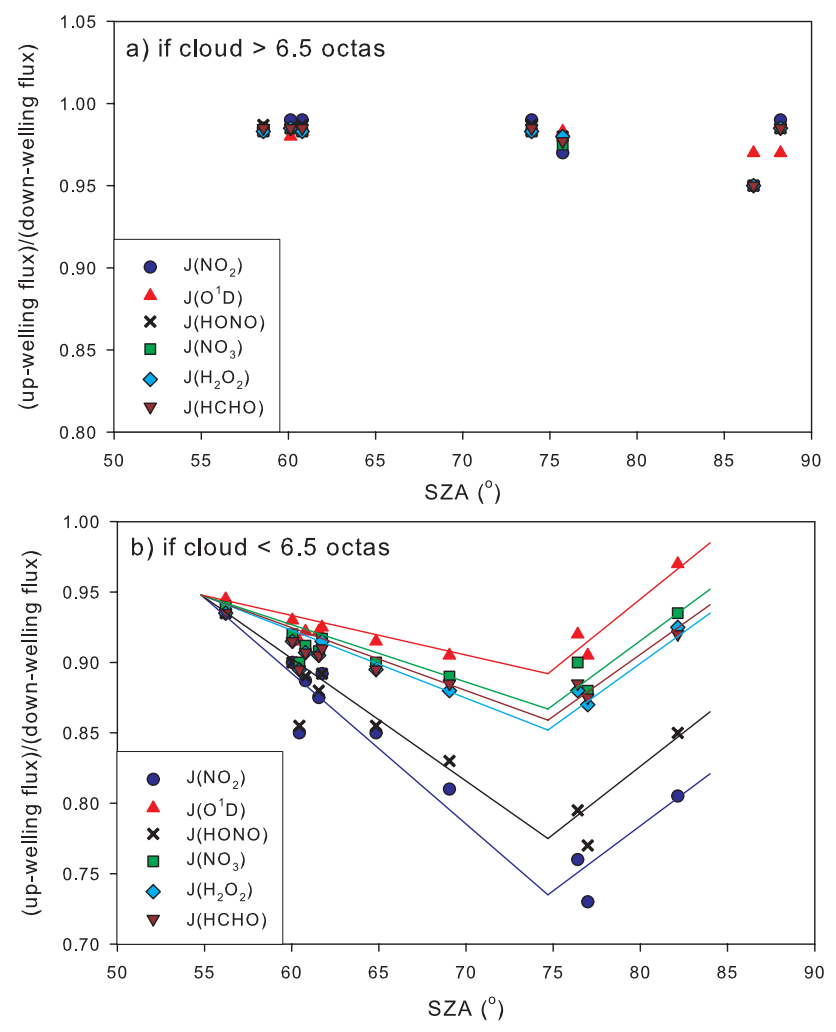

Fig. 13. Ratios of up-welling to down-welling fluxes derived from upward and downward hemispheric j-values (i.e. a 2-П average) for specific molecules. These were calculated from spectra measured by the actinic flux spectrometer at Halley in January and February 2005 (a) in cloudy conditions, and (b) less cloudy conditions, as a function of solar zenith angle (SZA). In the upper plot, the flux ratio is constant with SZA and molecule (wavelength), and has a variability of around $0.5 \%$. Pairs of straight lines in the lower plot are fits by eye to the points, to enable users to estimate flux ratios in less cloudy conditions within a few percent, interpolated to SZA values, on any day of the year. The flux ratio in cloudy conditions is, on average, 0.98 irrespective of wavelength.

re-clamping took 2 to $4 \mathrm{~min}$. Measurements of up-welling flux were made for 5 to $15 \mathrm{~min}$ before restoring the spectrometer to its upwards pointing position. Sometimes three or four successive up-welling measurements were made at intervals of 10 to $15 \mathrm{~min}$.

Rather than derive up-welling/down-welling flux ratios at each of the 512 wavelengths measured by the spectrometer (which would have been unwieldy for the user), we derived flux ratios from $j$-values for specific molecules calculated from the spectra. These quantities are much more useful for most atmospheric chemistry models. Ideally the ratio would be derived from simultaneous down-welling and up-welling measurements, but as our measurements were not simultaneous we had to use a modified approach. Instead, measurements of up-welling flux were compared with those of the down-welling flux at the start and end of each set of upwelling measurements. The up-welling data were then ad- justed by various trial factors, by eye, until they best matched the down-welling flux. The factor that best achieved this match was taken as the flux ratio. To assess the accuracy of this approach, the adjusted up-welling data were compared with an interpolation line achieved by linearly interpolating across missing down-welling data. Disagreement from this interpolation line was sometimes as large as $1 \%$, which suggests this value as an upper limit to the error on flux ratio measurement. A set of successive up-welling measurements was treated as one flux ratio measurement.

Results are given in Fig. 13, divided into measurements during more cloud and less cloud. The dividing value for cloudiness was between 6 and 7 octas ( 1 octa is 1/8 cloud cover), chosen by examination. The cloudy measurements gave a flux ratio of about 0.98 , more or less independent of solar zenith angle (SZA).

The less-cloudy measurements (shown in Fig. 13a) did not give a constant flux ratio, but had minimum flux ratios between $72^{\circ}$ and $78^{\circ} \mathrm{SZA}$. The reduction in flux ratio with increasing SZA is expected from the $\cos (\mathrm{SZA})$ dependency (Madronich 1987) discussed above. The increase at larger SZA can be explained by a greater proportion of the illumination coming from light scattered isotropically by air molecules (Rayleigh scattering) as SZA increases. The decrease in flux ratio is smaller at $\mathrm{UV}$ wavelengths (e.g. $j \mathrm{O}^{1} \mathrm{D}$ ) because the Rayleigh scattering is much larger for UV light.

Some users of CHABLIS data will require parameterised equations for the flux ratio, and fits over the range of SZA in Fig. 13 allow interpolation outside the summer period. We experimented with fitting polynomials, but they were generally less representative than the pairs of straight lines shown in the figure. These were fitted by eye, as there are too few points at $\mathrm{SZA}>75^{\circ}$ for a formal least-squares fit, and the observations are within a few percent of the lines chosen. Coordinates of the line pairs are listed in Table 4. The average flux ratio derived from these data is 0.89 .

Variability around the lines was several percent, which is probably due to variability in the age of the snow since it fell, as aging reduces albedo. For example, in the snow model of Flanner and Zender (2006), the albedo of fresh snow decreased by 2 to $9 \%$ over 5 to 10 days, depending on temperature and grain size. If chemical model comparisons of CHABLIS data demanded flux ratios accurate to better than a few percent, the time since snowfall could be used to improve the parameterisation in Table 4.

\section{Key findings from CHABLIS}

As described above, CHABLIS had three specific science foci, i) seasonal studies of oxidant chemistry, ii) year-round studies of the $\mathrm{NO}_{\mathrm{y}}$ budget, and iii) air/snow transfer studies. Advances were made in each of these three areas of study and the broad conclusions are presented here. 
The year-round measurements of $\mathrm{BrO}$ and $\mathrm{IO}$ made during CHABLIS revealed the key role of halogens in determining boundary layer chemistry at Halley. A springtime maximum in both radicals was measured, the observed IO peak at 20 pptv (Saiz-Lopez et al., 2007) having only recently been exceeded (Whalley et al., 2007). The NMHC data gathered during CHABLIS allowed a kinetic analysis that revealed significant concentrations of both $\mathrm{Cl}$ and $\mathrm{Br}$ atoms during ozone depletion events (ODEs), with $\mathrm{Cl}$ in the range $1.7 \times 10^{3}$ to $3.4 \times 10^{4}$ atom $\mathrm{cm}^{-3}$ and $\mathrm{Br}$ in the range $1.4 \times 10^{6}$ to $2.9 \times 10^{7}$ atom $\mathrm{cm}^{-3}$ (Read et al., 2007). A further analysis using NMHC data revealed a persistent background $\mathrm{Cl}$ atom concentration in August of $2.3 \times 10^{3}$ atom $\mathrm{cm}^{-3}$ (Read et al., 2007).

Measurements of $\mathrm{OH}$ and $\mathrm{HO}_{2}$ by FAGE during the austral summer produced the longest duration dataset yet achieved by that instrument (Bloss et al., 2007). Concentrations were lower than measured at South Pole (Mauldin et al., 2001), and were more in line with data captured at Palmer Station, another coastal Antarctic site (Jefferson et al., 1998). Elevated levels of $\mathrm{NO}_{\mathrm{x}}$ released from the snowpack (Bauguitte et al., $2008^{2}$ ) contributed to enhancements in $\mathrm{OH}$ concentrations through $\mathrm{HOx}$ cycling. However, $\mathrm{CH}_{3} \mathrm{O}_{2}-\mathrm{HO}_{2}-\mathrm{OH}$ conversion was dominated by the halogen oxides, IO and $\mathrm{BrO}$ (Bloss et al., 2007), which were still present during the summer at mixing ratios of around $2 \mathrm{pptv}$, with peaks to 5 pptv (Saiz-Lopez et al., 2007). The halogens were also responsible for controlling the $\mathrm{NO} / \mathrm{NO}_{2}$ ratio at this site (Bauguitte et al., $2007^{2}$ ). This overarching key role for halogens in boundary layer oxidant chemistry was completely unanticipated, and the results have led to a step-change in our thinking and understanding.

The partitioning of boundary layer $\mathrm{NO}_{\mathrm{y}}$ is explored in greater detail than previously reported for an Antarctic site (Jones et al., 2007). The nitrate radical remained below the 2 pptv instrumental detection limit throughout the duration of the campaign. Unfortunately this threshold is too high to explore upper limits to $\mathrm{NO}_{3}$ chemistry including any role for this oxidant within the boundary layer. Organic components (peroxyacetyl nitrate and methyl nitrate) overwhelmingly dominate the budget during the winter months, but are in no way associated with concentrations of nitrate measured in newly fallen snow. There thus appears to be no direct link between organic $\mathrm{NO}_{\mathrm{y}}$ and the ice core nitrate record. The measurements of nitrate in snow (and hence the nitrate record in ice) appear to be closely linked to inorganic species, with summertime peaks apparent both in surface snow nitrate and the inorganic species $\mathrm{HNO}_{3}$ and $\mathrm{HONO}$. The control over

\footnotetext{
${ }^{2}$ Bauguitte, S. J-B., Bloss, W. J., Evans, M. E., Jones, A. E., Lee, J. D., Mills, G.P., Saiz-Lopez, A., Salmon, R. A., Roscoe, H. K., and Wolff, E. W.: Summertime $\mathrm{NO}_{\mathrm{x}}$ measurements during the CHABLIS campaign: can source and sink estimates unravel observed diurnal cycles?, Atmos. Chem. Phys. Discuss., in preparation, 2008.
}

Table 4. Co-ordinates of line pairs from the interpolation lines of Fig. 13a which show up-welling/down-welling actinic flux ratios versus solar zenith angle when cloud cover $<6.5$ octas.

\begin{tabular}{lccc}
\hline $\mathrm{SZA}\left(^{\circ}\right)$ & 54.8 & 74.7 & 84.0 \\
\hline$j \mathrm{O}^{1} \mathrm{D}$ & 0.948 & 0.892 & 0.985 \\
$j \mathrm{NO}_{2}$ & 0.948 & 0.735 & 0.821 \\
$j \mathrm{HONO}$ & 0.948 & 0.775 & 0.865 \\
$j \mathrm{HCHO}$ & 0.948 & 0.859 & 0.941 \\
$\mathrm{JNO}_{3}$ & 0.948 & 0.867 & 0.952 \\
$j \mathrm{H}_{2} \mathrm{O}_{2}$ & 0.948 & 0.852 & 0.935 \\
\hline
\end{tabular}

these peaks, and whether the atmosphere is controlling snow or vice versa requires further study. Nitrite in snow is present in very low concentrations, but with its relatively fast photolysis rate, can also be a significant source of $\mathrm{NO}_{\mathrm{x}}$ to the boundary layer.

The range of species measured for the $\mathrm{NO}_{\mathrm{y}}$ budget study allowed an assessment of $\mathrm{NO}_{\mathrm{x}}$ sources to the boundary layer. Kinetic analyses were carried out for two case studies, one in summer and one in spring. In both cases, the production rate for boundary layer $\mathrm{NO}_{\mathrm{x}}$ was dominated by emissions from the snowpack; they were more important than any other gas phase reservoir and indeed greater than the integrated gasphase source. This finding suggests that for certain periods in the Earth's past history, it will be possible to calculate concentrations of Antarctic boundary layer $\mathrm{NO}_{\mathrm{x}}$ by using the ice core nitrate record.

Taken as a whole, the CHABLIS campaign clearly reveals that the chemistry of the coastal Antarctic boundary layer can only be understood if we consider both the active snow photochemistry that dominates the continental interior region, and the halogen chemistry that dominates the sea ice zone. To understand what is eventually preserved in snowpack and hence in ice cores, it remains essential to follow all these processes, and the resulting air-snow fluxes, throughout the year.

\section{Summary}

CHABLIS was an ambitious programme of atmospheric and snowpack sampling that built strongly on existing research. The results have provided exciting new insights into the way the polar atmosphere functions in coastal regions and provided step changes in our understanding about some of the chemical processes occurring there. Antarctica is a vast continent, and a real understanding of its boundary layer chemistry is essential if we are, for example, to access the rich ice core record of past atmospheric, climatic and environmental changes. The CHABLIS campaign has demonstrated what can be achieved with a very limited number of researchers in the field. It provides a model for others to follow in order to extend atmospheric chemistry research in this inhospitable environment. 
Acknowledgements. We are grateful to the Technical Services and Operations/Logistics staff of the British Antarctic Survey, and their creative approaches to solving numerous problems encountered along the way. We thank also the other overwintering staff at Halley who carried out the aerosol sampling programme and Steve Colwell for providing meteorological data. We are indebted to the Natural Environment Research Council Antarctic Funding Initiative (grant number NER/G/S/2001/00010) for providing us with the grant to fund this project. Additional support for fieldwork and data analysis respectively came from the BAS core-funded projects SAGES-AIR and CACHE-CEFAC. We would also like to thank the National Centre for Atmospheric Science Universities Facility for Atmospheric Measurements, NCAS-UFAM, for support of the FAGE instrument. CHABLIS contributes to the IGAC task on Air-Ice Chemical interactions (AICI).

Edited by: A. Hofzumahaus

\section{References}

Berresheim, H. and Eisele, F. L.: Sulfur Chemistry in the Antarctic Troposphere Experiment: An overview of the Project SCATE, J. Geophys. Res., 103(D1), 1619-1627, 1998.

Bloss, W. J., Lee, J. D., Heard, D. E., Salmon, R. A., Bauguitte, S. J.-B., Roscoe, H. K., and Jones, A. E.: Observations of $\mathrm{OH}$ and $\mathrm{HO}_{2}$ radicals in coastal Antarctica, Atmos. Chem. Phys., 7, 4171-4185, 2007,

http://www.atmos-chem-phys.net/7/4171/2007/.

Crawford, J. H., Davis, D. D., Chen, G., Buhr, M., Oltmans, S., Weller, R., Mauldin, L., Eisele, F., Shetter, R., Lefer, B., Arimoto, R., and Hogan, A.: Evidence for photochemical production of ozone at the South Pole surface, Geophys. Res. Lett., 28(19), 3641-3644, 2001.

CMDL (Climate Monitoring and Diagnostics Laboratory): Biennial Report 23 (1994/95), edited by: Hofmann, D. J., Peterson, J. T., and Rosson, R. M., Boulder, 1996.

Chu, L. and Anastasio, C.: Temperature and wavelength dependence of nitrite photolysis in frozen and aqueous solutions, Environ. Sci. Technol., 41, 3626-3632, 2007.

Davis, D., Nowak, J.B., Chen, G., Buhr, M., Arimoto, R., Hogan, A., Eisele, F., Mauldin, L., Tanner, D., Shetter, R., Lefer, B., and McMurry, P.: Unexpected high levels of NO observed at South Pole, Geophys. Res. Lett., 28, 3625-3628, 2001.

Davis, D., Chen, G., Buhr, M., Crawford, J., Lenschow, D., Lefer, B., Shetter, R., Eiselse, F., Mauldin, L., and Hogan, A.: South Pole $\mathrm{NO}_{\mathrm{x}}$ chemistry: an assessment of factors controlling variability and absolute levels, Atmos. Environ., 38, 5375-5388, 2004.

Elkins, J. W., Thompson, T. M., Swanson, T. H., Butler, J. H., Hall, B. D., Cummings, S. O., Fisher, D. A., and Raffo, A. G.: Decrease in the growth rates of atmospheric chlorofluorocarbons 11 and 12, Nature, 364, 780-783, 1993.

Flanner, M. G. and Zender, C. S.: Linking snowpack microphysics and albedo evolution, J. Geophys. Res., 111, D12208, doi:10.1029/2005JD006834, 2006.

Helmig, D., Oltmans, S. J., Carlson, D., Lamarque, J.-F., Jones, A., Labuschagne, C., Anlauf, K., and Hayden, K.: A review of surface ozone in the polar regions, Atmos. Environ., 41, 51385161, 2007.
Hofzumahaus, A., Lefer, B. L., Monks, P. S., Hall, S. R., Kylling, A., Mayer, B., Shetter, R. E., Junkermann, W., Bais, A., Calvert, J. G., Cantrell, C. A., Madronich, S., Edwards, G. D., Kraus, A., Müller, M., Bohn, B., Schmitt, R., Johnston, P., McKenzie, R., Frost, G. J., Griffioen, E., Krol, M., Martin, T., Pfister, G., Röth, E. P., Ruggaber, A., Swartz, W. H., Lloyd, S. A., and VanWeele, M.: Photolysis frequency of $\mathrm{O}_{3}$ to $\mathrm{O}\left({ }^{1} \mathrm{D}\right)$ : Measurements and Modeling during the International Photolysis Frequency Measurement and Model Intercomparison (IPMMI), J. Geophys. Res., 109, D08S90, doi:10.1029/2003JD004333, 2004.

Jacobi, H.-W., Weller, R., Jones, A. E., Anderson, P. S., and Schrems, O.: Peroxyacetyl nitrate (PAN) concentrations in the Antarctic troposphere measured during the photochemical experiment at Neumayer (PEAN “99), Atmos. Environ., 34, 52355247, 2000.

Jacobi, H.-W. and Hilker, B.: A mechanism for the photochemical transformation of nitrate in snow, J. Photochem. Photobiol. A, doi:10.1016/j.jphotochem.2006.06.039, 185, 371-382, 2007.

Jefferson, A., Tanner, D. J., Eisele, F. L., Davis, D. D., Chen, G., Crawford, J., Huey, J. W., Torres, A. L., and Berresheim, H.: $\mathrm{OH}$ Photochemistry and methane sulphonic acid formation in the coastal Antarctic boundary layer, J. Geophys. Res., 103, 16471656, 1998.

Jones, A. E., Weller, R., Minikin, A., Wolff, E. W., Sturges, W. T., McIntyre, H. P., Leonard, S. R., Schrems, O., and Bauguitte, S.: Oxidised nitrogen chemistry and speciation in the Antarctic troposphere, J. Geophys. Res. 104, 21 355-21 366, 1999.

Jones, A. E., Anderson, P. S., Wolff, E. W., Turner, J. T., Rankin, A. M., and Colwell, S. R.: A role for newly forming sea ice in springtime polar tropospheric ozone loss? Observational evidence from Halley station, Antarctica, J. Geophys. Res., 111, D08306, doi:10.1029/2005JD006566, 2006.

Jones, A. E., Wolff, E. W., Ames, D., Bauguitte, S. J.-B., Clemitshaw, K. C., Fleming, Z., Mills, G. P., Saiz-Lopez, A., Salmon, R. A., Sturges, W. T., and Worton, D. R.: The multi-seasonal $\mathrm{NO}_{\mathrm{y}}$ budget in coastal Antarctica and its link with surface snow and ice core nitrate: Results from the CHABLIS campaign, Atmos. Chem. Phys. Discuss., 7, 4127-4163, 2007, http://www.atmos-chem-phys-discuss.net/7/4127/2007/.

Jourdain, B. and Legrand, M.: Seasonal variations of atmospheric dimethylsulfide, dimethylsulfoxide, sulfur dioxide, methanesulfonate, and non- sea-salt sulfate aerosols at Dumont d'Urville (coastal Antarctica) (December 1998 to July 1999), J. Geophys. Res.-Atmos., 106, 14 391-14 408, 2001.

König-Langlo, G., King, J., and Pettre, P.: Climatology of the three coastal Antarctic stations Dumont d'Urville, Neumayer and Halley, J. Geophys. Res., 103, 10 935-10 946, 1998.

Li, S.-M.: Particulate and snow nitrite in the spring arctic troposphere, Atmos. Environ., 27A, 2959-2967, 1993.

Mauldin III, R. L., Eisele, F. L., Tanner, D. J., Kosciuch, E., Shetter, R., Lefer, B., Hall, S. R., Nowak, J. B., Buhr, M., Chen, G., Wang, P., and David, D.: Measurements of $\mathrm{OH}, \mathrm{H}_{2} \mathrm{SO}_{4}$, and MSA at the South Pole during ISCAT, Geophys. Res. Lett., 28, 3629-3632, 2001.

Murayama, S., Takakiyo, N., and Tanaka, M.: Variations of tropospheric ozone concentrations over Syowa Station, Antarctica, Tellus, 44B, 262-272, 1992.

Neff, W., Helmig, D., Grachev, A., and Davis, D.: A study of 
boundary layer behavior associated with high NO concentrations at the South Pole using a minisodar, tethered balloon and sonic anemometer, Atmos. Environ., 42(12), 2762-2779, 2008.

Oltmans, S. J. and Komhyr, W. D.: Surface ozone in Antarctica, J. Geophys. Res., 81, 5359-5364, 1976.

Oncley, S. P., Buhr, M., Lenschow, D. H., Davis, D, and Semmer, S. R.: Observations of summertime NO fluxes and boundary-layer height at South Pole during ISCAT 2000 using scalar similarity, Atmos. Environ., 38, 5389-5398, 2004.

Read, K. A., Lewis, A. C., Salmon, R. S., Jones A. E., and Bauguitte, S.: $\mathrm{OH}$ and halogen atom influence on the variability of non-methane hydrocarbons in the Antarctic boundary layer, Tellus B, 59, 22-38, 2007.

Riedel, K., Weller, R., and Schrems, O.: Variability of formaldehyde in the Antarctic troposphere, Phys. Chem. Chem. Phys., 1, 5523-5527, 1999.

Riedel, K., Weller, R., Schrems, O., and König-Langlo, G.: Variability of tropospheric hydroperoxides at a coastal surface site in Antarctica, Atmos. Environ., 34, 5225-5234, 2000.

Ryerson, T. B., Huey, L. G., Knapp, K., Neuman, J. A., Parrish, D. D., Sueper, D. T., and Fehsenfeld, F. C.: Design and initial characterization of an inlet for gas-phase $\mathrm{NO}_{\mathrm{y}}$ measurements from aircraft, J. Geophys. Res., 104(D5), 5483-5492, 1999.

Saiz-Lopez, A., Mahajan, A. S., Salmon, R. A., Bauguitte, S. J.B., Jones, A. E., Roscoe, H. K., and Plane, J. M. C.: Boundary layer halogens in coastal Antarctica, Science, 317(5836), 348351, 2007.

Savarino, J., Kaiser, J., Morin, S., Sigman, D. M., and Thiemens, M. H.: Nitrogen and oxygen isotopic constraints on the origin of atmospheric nitrate in coastal Antarctica, Atmos. Chem. Phys., 7, 1925-1945, 2007, http://www.atmos-chem-phys.net/7/1925/2007/.

Simpson, W. R., von Glasow, R., Riedel, K., Anderson, P., Ariya, P., Bottenheim, J., Burrows, J., Carpenter, L. J., Frie, U., Goodsite, M. E., Heard, D., Hutterli, M., Jacobi, H.-W., Kaleschke, L., Neff, B., Plane, J., Platt, U., Richter, A., Roscoe, H., Sander, R., Shepson, P., Sodeau, J., Steffen, A., Wagner, T., and Wolff, E.: Halogens and their role in polar boundary-layer ozone depletion, Atmos. Chem. Phys., 7, 4375-4418, 2007, http://www.atmos-chem-phys.net/7/4375/2007/.
Wagenbach, D., Legrand, M., Fischer, H., Pichlmayer, F., and Wolff, E.W.: Atmospheric near-surface nitrate at coastal Antarctic sites, J. Geophys. Res., 103(D9), 11 007-11 020, 1998.

Weller, R., Jones, A. E., Wolff, E. W., Minikin, A., Anderson, P. S., KönigLanglo, G., and Schrems, O.: Investigating possible causes of the observed diurnal variability in Antarctic $\mathrm{NO}_{\mathrm{y}}$, Geophys. Res. Lett., 26, 2853-2856, 1999.

Weller, R., Jones, A. E., Wille, A., Jacobi, H.-W., McIntyre, H. P., Huke, M., and Wagenbach, D.: Seasonality of reactive nitrogen oxides $\left(\mathrm{NO}_{y}\right)$ at Neumayer Station, Antarctica, J. Geophys. Res., 107(D23), 4673, doi:10.1029/2002JD002495, 2002.

Wessel, S., Aoki, S., Winkler, P., Weller, R., Herber, A., Gerhandt, H., and Schrems, O.: Tropospheric ozone depletion in polar regions - A comparison of observations in the Arctic and Antarctic, Tellus, 50B, 34-50, 1998.

Whalley, L. K., Furneaux, K. L., Gravestock, T., Atkinson, H. M., Bale, C. S. E., Ingham, T., Bloss, W. J., and Heard, D. E.: Detection of iodine monoxide radicals in the marine boundary layer using laser induced fluorescence spectroscopy, J. Atmos. Chem., 58, 19-39, 2007.

Wolff, E. W., Legrand, M. R., and Wagenbach, D.: Coastal Antarctic aerosol and snowfall chemistry, J. Geophys. Res., 103, 10927-10 934, 1998.

Wolff, E. W., Jones, A. E., Bauguitte, S. J.-B., and Salmon, R. A.: Reassessment of the factors controlling temporal profiles of nitrate in polar ice cores using evidence from snow and atmospheric measurements, Atmos. Chem. Phys. Discuss., 8, 11039 $11062,2008$.

Wyputta, U.: Untersuchung zum Spurenstofftransport in die Antarctis anhand von Messungen an der Georg-von-NeumayerStation, PhD Thesis, Hamburg. Berichte aus dem Zentrum fuer Meeres-und-Klimaforschung Reihe A, No. 15, 1994. 